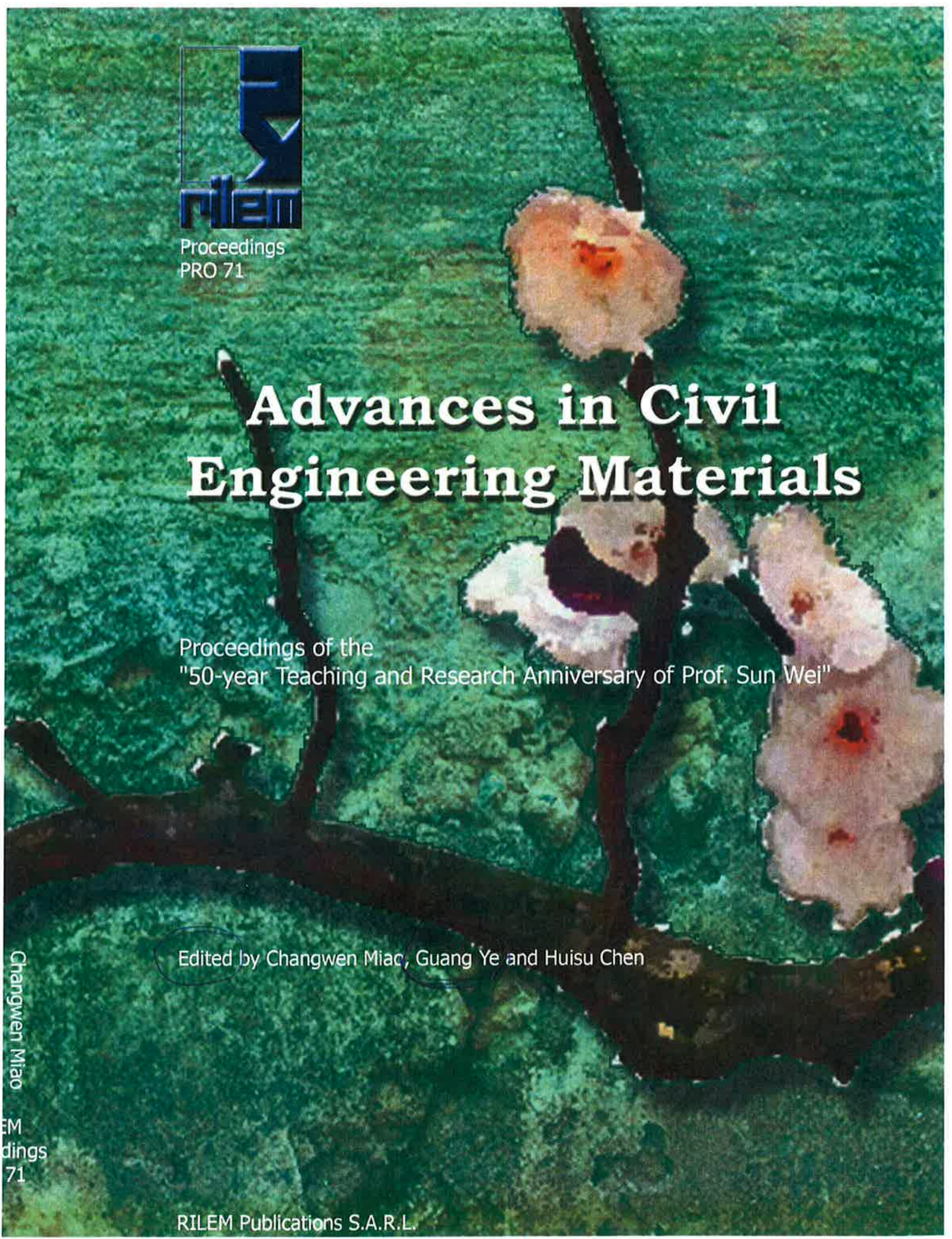




\section{Advances in Civil Engineering Materials}

The 50-year 'Teaching and Research Anniversary of Prof. Sun Wei

15 October 2008

Nanjing, China 
Advances in Civil Engineering Materials

The 50-year Teaching and Research Anniversary of Prof. Sun Wei, 15 October 2008, Nanjing, China

Published by RILEM Publications s.a.r.l.

157 rue des Blains F-92220 Bagneux - France

Tel : + $33145361020 \quad$ Fax : + 33145366320

http://www.rilem.net E-mail: dg@,rilem.net

(C) 2010 RILEM - Tous droits réservés. ISBN: 978-2-35158-098-1

e-ISBN : 978-2-35158-099-8

Publisher's note: this book has been produced from pdf files provided by the individual contributors. In the absence of some of the original source files, limited editorial adjustments and corrections were possible. The publisher makes no representation, express or implied, with regard to the accuracy of the information contained in this book and cannot accept any legal responsibility or liability for any errors or omissions that may be made.

All titles published by RILEM Publications are under copyright protection; said copyrights being the property of their respective holders. All Rights reserved.

No part of any book may be reproduced or transmitted in any form or by any means, graphic, electronic, or mechanical, including photocopying, recording, taping, or by any information storage or retrieval system, without the permission in writing from the publisher.

RILEM, The International Union of Laboratories and Experts in Construction Materials, Systems and Structures, is a non profit-making, non-governmental technical association whose vocation is to contribute to progress in the construction sciences, techniques and industries, essentially by means of the communication it fosters between research and practice. RILEM's activity therefore aims at developing the knowledge of properties of materials and performance of structures, at defining the means for their assessment in laboratory and service conditions and at unifying measurement and testing methods used with this objective.

RILEM was founded in 1947, and has a membership of over 900 in some 70 countries. It forms an institutional framework for co-operation by experts to:

- optimise and harmonise test methods for measuring properties and performance of building and civil engineering materials and structures under laboratory and service environments,

- prepare technical recommendations for testing methods,

- prepare state-of-the-art reports to identify further research needs,

- collaborate with national or international associations in realising these objectives.

RILEM members include the leading building research and testing laboratories around the world, industrial research, manufacturing and contracting interests, as well as a significant number of individual members from industry and universities. RILEM's focus is on construction materials and their use in building and civil engineering structures, covering all phases of the building process from manufacture to use and recycling of materials.

RILEM meets these objectives through the work of its technical committees. Symposia, workshops and seminars are organised to facilitate the exchange of information and dissemination of knowledge. RILEM's primary output consists of technical recommendations. RILEM also publishes the journal Materials and Structures which provides a further avenue for reporting the work of its committees. Many other publications, in the form of reports, monographs, symposia and workshop proceedings are produced. 


\section{Advances in Civil Engineering Materials}

The 50-year Teaching and Research Anniversary of Prof. Sun Wei

Nanjing, China

October 15,2008

Edited by

Changwen Miao, Guang Ye and Huisu Chen 


\section{RILEM Publications}

RILEM Publications are presented in 6 collections, corresponding to the 5 clusters of active RILEM Technical Committees, sorted by fields of expertise, and a 6th multi-thematic collection dedicated to journals and compendiums:

A. Mechanical Performance and Fracture

B. Test Methods, Materials Characterization and Processing

C. Service Life and Design

D. Durability and Deterioration Mechanisms

E. Bitumen, Masonry and Timber

F. Journals and Compendiums

Each publication is assigned to one of the following series: reports (REP), proceedings (PRO), compendiums (COMP) and journals. The former CD-ROM series is now included in one of these series.

Each publication is available in at least one of the three following editions: print (PR), CD or DVD-ROM (CD), or online (OL).

Online editions are available through our web site, at http://www.rilem.net

The RILEM DVD-ROM, gathering several thousands of online articles, is also published and updated each year (internal publication, circulation restricted to RILEM Benefactor Members).

The following list is presenting our global offer, sorted by series.

\section{RILEM PROCEEDINGS}

PRO 1: Durability of High Performance Concrete (ISBN: 2-912143-03-9); Ed. H. Sommer

PRO 2: Chloride Penetration into Concrete (ISBN: 2-912143-00-04), Eds. L.-O. Nilsson and J.-P. Ollivier

PRO 3: Evaluation and Strengthening of Existing Masonry Structures (ISBN: 2-912143-02-0); Eds. L. Binda and C. Modena

PRO 4: Concrete: From Material to Structure (ISBN: 2-912143-04-7), Eds. J.-P. Bournazel and Y. Malier

PRO 5: The Role of Admixtures in High Performance Concrete (ISBN: 2-912143-05-5); Eds. J. G. Cabrera and R. Rivera-Villarreal

PRO 6: High Performance Fiber Reinforced Cement Composites (HPFRCC 3) (ISBN: 2-91214306-3); Eds. H. W. Reinhardt and A. E. Naaman

PRO 7: 1st International RILEM Symposium on Self-Compacting Concrete (ISBN: 2-912143-098); Eds. A. Skarendahl and Ö. Petersson

PRO 8: International RILEM Symposium on Timber Engineering (ISBN: 2-912143-10-1);

Ed. L. Boström

PRO 9: 2nd International RILEM Symposium on Adhesion between Polymers and Concrete ISAP '99 (ISBN: 2-912143-11-X); Eds. Y. Ohama and M. Puterman 
PRO 10: 3rd International RILEM Symposium on Durability of Building and Construction Sealants (ISBN: 2-912143-13-6); Eds. A. T. Wolf

PRO 11: 4th International RILEM Conference on Reflective Cracking in Pavements (ISBN: 2912143-14-4); Eds. A. O. Abd El Halim, D.A. Taylor and El H. H. Mohamed

PRO 12: International RILEM Workshop on Historic Mortars: Characteristics and Tests (ISBN: 2-912143-15-2); Eds. P. Bartos, C. Groot and J. J. Hughes

PRO 13: 2nd International RILEM Symposium on Hydration and Setting (ISBN: 2-912143-16$0) ;$ Ed. A. Nonat

PRO 14: Integrated Life-Cycle Design of Materials and Structures (ILCDES 2000) (ISBN: $951-$ 758-408-3), (ISSN: 0356-9403); Ed. S. Sarja

PRO 15: Fifth RILEM Symposium on Fibre-Reinforced Concretes (FRC) - BEFIB' 2000 (ISBN: 2-912143-18-7); Eds. P. Rossi and G. Chanvillard

PRO 16: Life Prediction and Management of Concrete Structures (ISBN: 2-912143-19-5); Ed. D. Naus

PRO 17: Shrinkage of Concrete - Shrinkage 2000 (ISBN: 2-912143-20-9)

Eds. V. Baroghel-Bouny and P.-C. Aitcin

PRO 18: Measurement and Interpretation of the On-Site Corrosion Rate (ISBN: 2-912143-21-7)

Eds. C. Andrade, C. Alonso, J. Fullea, J. Polimon and J. Rodriguez

PRO 19: Testing and Modelling the Chloride Ingress into Concrete - 516 pp. - ISBN: 2-91214322-5 - Soft cover, Eds. C. Andrade and J. Kropp

PRO 20: 1st International RILEM Workshop on Microbial Impacts on Building Materials (2000); Ed. M. Ribas Silva (CD 02)

PRO 21: International RILEM Symposium on Connections between Steel and Concrete (ISBN: 2-912143-25-X); Ed. R. Eligehausen

PRO 22: International RILEM Symposium on Joints in Timber Structures (ISBN: 2-912143-284); Eds. S. Aicher and H.-W. Reinhardt

PRO 23: International RILEM Conference on Early Age Cracking in Cementitious Systems (ISBN: 2-912143-29-2); Eds. K. Kovler and A. Bentur

PRO 24: 2nd International RILEM Workshop on Frost Resistance of Concrete (ISBN: 2-91214330-6) Hard back; Eds. M. J. Setzer, R. Auberg and H.-J. Keck

PRO 25: International RILEM Workshop on Frost Damage in Concrete (ISBN: 2-912143-31-4) Soft cover; Eds. D. J. Janssen, M. J. Setzer and M. B. Snyder

PRO 26: International RILEM Workshop on On-Site Control and Evaluation of Masonry Structures (ISBN: 2-912143-34-9) - Soft cover; Eds. L. Binda and R. C. de Vekey

PRO 27: International RILEM Symposium on Building Joint Sealants (1988) (CD03); Ed. A.T. Wolf, 2003

PRO 28: 6th International RILEM Symposium on Performance Testing and Evaluation of Bituminous Materials, PTEBM'03, Zurich, Switzerland (2003) (ISBN: 2-912143-35-7) - Soft cover; Ed. M.N. Partl, (CD06)

PRO 29: 2nd International RILEM Workshop on Life Prediction and Ageing Management of Concrete Structures, Paris, France (2003) (ISBN: 2-912143-36-5) - Soft cover; Ed. D.J. Naus 
Advances in Civil Engineering Materials

The 50-year Teaching and Research Anniversary of Prof. Sun Wei, 15 October 2008, Nanjing, China

PRO 30: 4th International RILEM Workshop on High Performance Fiber Reinforced Cement Composites - HPFRCC 4, University of Michigan, Ann Arbor, USA (2003) (ISBN: 2-912143-373) Hard back; Eds. A.E. Naaman and H.W. Reinhardt

PRO 31: International RILEM Workshop on Test and Design Methods for Steel Fibre Reinforced Concrete: Background and Experiences (2003) (ISBN: 2-912143-38-1) - Soft cover; $E d s . B$. Schnütgen and L. Vandewalle

PRO 32: International Conference on Advances in Concrete and Structures (2003), 2 vol. (ISBN (set): 2-912143-41-1) - Soft cover; Eds. Ying-shu Yuan. Surendra P. Shah and Heng-lin Lü

PRO 33: 3rd International Symposium on Self-Compacting Concrete (2003) (ISBN: 2-91214342-X) - Soft cover; Eds. Ó. Wallevik and I. Nielsson

PRO 34: International RILEM Conference on Microbial Impact on Building Materials (2003) (ISBN: 2-912143-43-8); Ed. M. Ribas Silva

PRO 35: International RILEM TC 186-ISA on Internal Sulfate Attack and Delayed Ettringite Formation (2002) (ISBN: 2-912143-44-6) - Soft cover; Eds. K. Scrivener and J. Skalny

PRO 36: International RILEM Symposium on Concrete Science and Engineering - A Tribute to Arnon Bentur (2004) (ISBN: 2-912143-46-2) Hard back

Eds. K. Kovler, J. Marchand, S. Mindess and J. Weiss

PRO 37: 5th International RILEM Conference on Cracking in Pavements - Mitigation, Risk Assessment and Prevention (2004), (ISBN: 2-912143-47-0) Hard back

Eds. C. Petit, I. Al-Qadi and A. Millien

PRO 38: 3rd International RILEM Workshop on Testing and Modelling the Chloride Ingress into Concrete (2002) (ISBN: 2-912143-48-9) - Soft cover; Eds. C. Andrade and J. Kropp

PRO 39: 6th International RILEM Symposium on Fibre-Reinforced Concretes (BEFIB 2004), (ISBN: 2-912143-51-9) Hard back; Eds. M. Di Prisco, R. Felicetti and G. A. Plizzari

PRO 40: International RILEM Conference on the Use of Recycled Materials in Buildings and Structures (2004) (ISBN: 2-912143-52-7) - Soft cover; Eds. E. Vázquez, Ch. F. Hendriks and G. M. T. Janssen

PRO 41: RILEM International Symposium on Environment-Conscious Materials and Systems for Sustainable Development (2004) (ISBN: 2-912143-55-1) - Soft cover; Eds. N. Kashino and Y. Ohama

PRO 42: SCC'2005 - China: 1st International Symposium on Design, Performance and Use of Self-Consolidating Concrete (2005) (ISBN: 2-912143-61-6) Hard back; Eds. Zhiwu Yu, Caijun Shi, Kamal Henri Khayat and Youjun Xie

PRO 43: International RILEM Workshop on Bonded Concrete Overlays (2004) (e-ISBN: 2-912143-83-7); Eds. J.L. Granju and J. Silfwerbrand

PRO 44: 2nd International RILEM Workshop on Microbial Impacts on Building Materials (Brazil 2004) (CD11) e-ISBN: 2-912143-84-5; Ed. M. Ribas Silva

PRO 45: 2nd International Symposium on Nanotechnology in Construction, Bilbao, Spain (2005) - ISBN: 2-912143-87-X - Soft cover; Eds. Peter J.M. Bartos, Yolanda de Miguel and Antonio Porro; 2006

PRO 46: ConcreteLife'06 - International RILEM-JCI Seminar on Concrete Durability and Service Life Planning: Curing, Crack Control, Performance in Harsh Environments (2006) - ISBN: 2912143-89-6, Hard back; Ed. K. Kovler 
Advances in Civil Engineering Materials

The 50-year Teaching and Research Anniversary of Prof. Sun Wei, 15 October 2008, Nanjing, China

PRO 47: International RILEM Workshop on Performance Based Evaluation and Indicators for Concrete Durability (2006) - ISBN: 978-2-912143-95-2-Soft cover; Eds. V. Baroghel-Bouny, C. Andrade, R. Torrent and K. Scrivener ; 2007

PRO 48: 1st International RILEM Symposium on Advances in Concrete through Science and Engineering (2004) e-ISBN: 2-912143-92-6; Eds. J. Weiss, K. Kovler, J. Marchand, and S. Mindess

PRO 49: International RILEM Workshop on High Performance Fiber Reinforced Cementitious Composites in Structural Applications (2006) ISBN: 2-912143-93-4 - Soft cover; Eds. G. Fischer and V.C. Li

PRO 50: $1^{\text {st }}$ International RILEM Symposium on Textile Reinforced Concrete (2006) ISBN: 2912143-97-7 - Soft cover; Eds. Josef Hegger, Wolfgang Brameshuber and Norbert Will

PRO 51: $2^{\text {nd }}$ International Symposium on Advances in Concrete through Science and Engineering (2006) ISBN: 2-35158-003-6; e-ISBN: 2351580028 Hard back; Eds. J. Marchand, B. Bissonnette, R. Gagné, M. Jolin and F. Paradis

PRO 52: Volume Changes of Hardening Concrete: Testing and Mitigation (2006) ISBN: 235158-004-4; e-ISBN: 2351580052 - Soft cover; Eds. O. M. Jensen, P. Lura and K. Kovler

PRO 53: High Performance Fiber Reinforced Cement Composites HPFRCC5 (2007) 542 pp. ISBN: 978-2-35158-046-2 Hard back; Eds. H.W. Reinhardt and A.E. Naaman

PRO 54: $5^{\text {th }}$ International RILEM Symposium on Self-Compacting Concrete (2007) $1198 \mathrm{pp}$. ISBN: 978-2-35158-047-9 - Soft cover; Eds. G. De Schutter and V. Boel

PRO 55: International RILEM Symposium Photocatalysis, Environment and Construction Materials (2007) 350 pp. ISBN: 978-2-35158-056-1 - Soft cover; Eds. P. Baglioni and L. Cassar PRO56: International RILEM Workshop on Integral Service Life Modelling of Concrete Structures (2007) 458 pp. ISBN 978-2-35158-058-5 - Hard back, Eds. R. M. Ferreira, J. Gulikers and C. Andrade

PRO57: RILEM Workshop on Performance of cement-based materials in aggressive aqueous environments (2008) 132 pp. e-ISBN: 978-2-35158-059-2, Ed. N. De Belie

PRO58: International RILEM Symposium on Concrete Modelling CONMOD'08 (2008) 847 pp., ISBN: 978-2-35158-060-8, Soft cover, Eds. E. Schlangen and G. De Schutter

PRO 59: International RILEM Conference on On Site Assessment of Concrete, Masonry and Timber Structures SACoMaTiS 2008 (2008)., ISBN: 978-2-35158-061-5 (set) - Hard back, Eds. L. Binda, M. di Prisco and R. Felicetti

PRO 60: Seventh RILEM International Symposium (BEFIB 2008) on Fibre Reinforced Concrete: Design and Applications (2008) 1181 pp, ISBN: 978-2-35158-064-6 - Hard back, Ed. R. Gettu

PRO 61: $1^{\text {st }}$ International Conference on Microstructure Related Durability of Cementitious Composites (Nanjing), 2 volumes, (2008), 1524 pp., ISBN: 978-2-35158-065-3 - Soft cover, Edited by W. Sun, K. van Breugel, C. Miao, G. Ye and H. Chen

PRO 62: NSF/ RILEM Workshop: In-situ Evaluation of Historic Wood and Masonry Structures (2008), e-ISBN: 978-2-35158-068-4, Edited by B. Kasal, R. Anthony and M. Drdacky

PRO 63: Concrete in Aggressive Aqueous Environments: Performance, Testing and Modelling, 2 volumes, (2009) 594 pp., ISBN: 978-2-35158-071-4 - Soft cover, Eds. M.G. Alexander and A. Bertron 
Advances in Civil Engineering Materials

The 50-year Teaching and Research Anniversary of Prof. Sun Wei, 15 October 2008, Nanjing, China

PRO 64: Long Term Performance of Cementitious Barriers and Reinforced Concrete in Nuclear Power Plants and Waste Management - NUCPERF 2009 (2009), Soft cover - ISBN: 978-2-35158072-1, 359 pp., Edited by V. L'Hostis, R. Gens, C. Gallé

PRO 65: Design Performance and Use of Self-consolidating Concrete, SCC'2009, (2009), ISBN: 978-2-35158-073-8 - Eds. C. Shi, Z. Yu, K. H. Khayat and P. Yan

PRO 66: Concrete Durability and Service Life Planning, $2^{\text {nd }}$ International RILEM Workshop, ConcreteLife'09, (2009) 602 pp., ISBN: 978-2-35158-074-5 - Eds.K. Kovler, A. Bentur

PRO 67: Repairs Mortars for Historic Masonry, (2009) - 397 pp. - e-ISBN: 978-2-35158-083-7 Ed. by C. Groot

PRO 68: Proceedings of the $3^{\text {rd }}$ International RILEM Symposium on "Rheology of Cement Suspensions such as Fresh Concrete" - 372 pp. - ISBN 978-2-35158-091-2 - Edited by O. $H$. Wallevik, S. Kubens and S. Oesterheld

PRO 69: $3^{\text {rd }}$ International PhD Student Workshop on "Modelling the Durability of Reinforced Concrete" - ISBN: 978-2-35158-095-0 - Edited by R. M. Ferreira, J. Gulikers and C. Andrade

PRO 71: Advances in Civil Engineering Materials, Proceedings of the "The 50-year Teaching Anniversary of Prof. Sun Wei", ISBN: 978-2-35158-098-1, e-ISBN: 978-2-35158-099-8 - Edited by C. Miao, G. Ye, and H. Chen

\section{RILEM REPORTS}

Report 19: Considerations for Use in Managing the Aging of Nuclear Power Plant Concrete Structures (ISBN: 2-912143-07-1); Ed. D. J. Naus, 1999

Report 20: Engineering and Transport Properties of the Interfacial Transition Zone in Cementitious Composites (ISBN: 2-912143-08-X)

Eds. M. G. Alexander, G. Arliguie, G. Ballivy, A. Bentur and J. Marchand, 1999

Report 21: Durability of Building Sealants (ISBN: 2-912143-12-8); Eds. A. T. Wolf, 1999

Report 22: Sustainable Raw Materials - Construction and Demolition Waste (ISBN: 2-912143-17-9); Eds. C. F. Hendriks and H. S. Pietersen, 2000

Report 23: Self-Compacting Concrete state-of-the-art report (ISBN: 2-912143-23-3) - Soft cover; Eds. A. Skarendahl and $\ddot{O}$. Petersson, 2001

Report 24: Workability and Rheology of Fresh Concrete: Compendium of Tests (ISBN: 2-912143-32-2) - Soft cover; Eds. P.J.M. Bartos, M. Sonebi and A.K. Tamimi, 2002

Report 25: Early Age Cracking in Cementitious Systems (ISBN: 2-912143-33-0) - Soft cover Ed. A. Bentur, 2003

Report 26: Towards Sustainable Roofing (Joint Committee CIB/RILEM) (CD 07); Eds. Thomas W. Hutchinson and Keith Roberts, 2001

Report 27: Condition Assessment of Roofs (Joint Committee CIB/RILEM) (CD 08), 2003

Report 28: Final report of RULEM TC 167-COM 'Characterisation of Old Mortars with Respect to their Repair’, 192 pp. (ISBN: 978-2-912143-56-3) - Soft cover; Eds. C. Groot, G. Ashall and J. Hughes, 2007

Report 29: Pavement Performance Prediction and Evaluation (PPPE): Interlaboratory Tests, (eISBN: 2-912143-68-3); Eds. M. Partl and H. Piber, 2005 
Report 30: Final Report of RILEM TC 198-URM 'Use of Recycled Materials', (ISBN: 2912143-82-9; e-ISBN: 2-912143-69-1) - Soft cover; Eds. Ch. F. Hendriks, G.M.T. Janssen and E. Vázquez, 2005

Report 31: Final Report of RILEM TC 185-ATC 'Advanced testing of cement-based materials during setting and hardening', (ISBN: 2-912143-81-0; e-ISBN: 2-912143-70-5) - Soft cover; Eds. H.W. Reinhardt and C.U. Grosse, 2005

Report 32: Probabilistic Assessment of Existing Structures. A JCSS publication - 176pp. ISBN $2-$ 912143-24-1 - Hard back; Ed. D. Diamantidis, 2001

Report 33: State-of-the-Art Report of RILEM Technical Committee TC 184-IFE 'Industrial Floors', - 158 pp. ISBN 2-35158-006-0 - Soft cover; Ed. P. Seidler, 2006

Report 34: Report of RILEM Technical Committee TC 147-FMB 'Fracture mechanics applications to anchorage and bond' Tension of Reinforced Concrete Prisms - Round Robin Analysis and Tests on Bond, - 248 pp. e-ISBN 2-912143-91-8 - Online; Eds. L. Elfgren and K. Noghabai, 2001

Report 35: Final Report of RILEM Technical Committee TC 188-CSC 'Casting of Self Compacting Concrete', 40 pp. ISBN 2-35158-001-X; e-ISBN: 2-912143-98-5 - Soft cover; $E d s . A$. Skarendahl and P. Billberg, 2006

Report 36: State-of-the-Art Report of RILEM Technical Committee TC 201-TRC 'Textile Reinforced Concrete', 292 pp. ISBN 2-912143-99-3 - Soft cover; Ed. W. Brameshuber, 2006

Report 37: State-of-the-Art Report of RILEM Technical Committee TC 192-ECM 'Environmentconscious construction materials and systems', 88 pp. ISBN: 978-2-35158-053-0 - Soft cover; Eds. N. Kashino, D. Van Gemert and K. Imamoto, 2007

Report 38: State-of-the-Art Report of RILEM Technical Committee TC 205-DSC 'Durability of Self-Compacting Concrete', 204 pp. ISBN: 978-2-35158-048-6 - Soft cover; Eds. G. De Schutter and K. Audenaert, 2007

Report 39: Final Report of RILEM Technical Committee TC 187-SOC 'Experimental determination of the stress-crack opening curve for concrete in tension', $54 \mathrm{pp}$. ISBN 978-235158-049-3 - Soft cover; Ed. J. Planas, 2007

Report 40: State-of-the-Art Report of RILEM Technical Committee TC 189-NEC 'NonDestructive Evaluation of the Penetrability and Thickness of the Concrete Cover', $246 \mathrm{pp}$. ISBN 978-2-35158-054-7 - Soft cover; Eds. R. Torrent and L. Fernández Luco, 2007

Report 41: State-of-the-Art Report of RILEM Technical Committee TC 196-ICC 'Internal Curing of Concrete', 164 pp. ISBN 978-2-35158-009-7 - Soft cover; Eds. K. Kovler and O.M. Jensen, 2007

\section{RILEM COMPENDIUMS}

COMP 01: Trilingual Dictionary for Materials and Structures (English-French-German) (CD01) (1970)

COMP 02: 1947-1997: 50 years of evolution of Building Materials and Structures - e-ISBN: 2-912143-86-1; Ed. F. Wittmann

COMP 03: General Conference of RILEM TCs' Chairmen and RILEM Seminar 'Advancing the Knowledge in Materials and Structures' (CD10) (2000) e-ISBN: 2-912143-85-3

COMP 06: Concrete Science and Engineering Journal - Vol. 1, 2, 3, 4 (1999-2002) (CD05)

COMP 13: RILEM Technical Day, Moscow (2005) e-ISBN: 2-35158-045-1 


\section{Organized by}
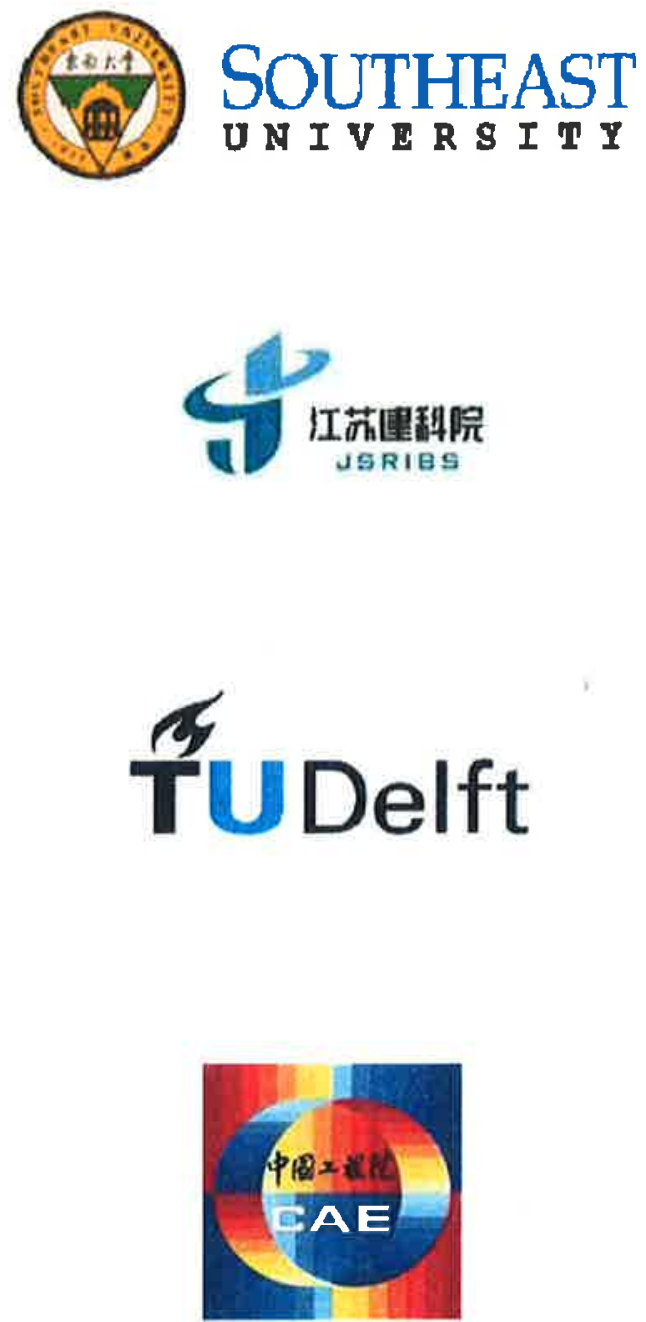


\section{Workshop of 50-years Anniversary of}

\section{Prof. Sun Wei in Teaching and Research}

15 October, 2008

Nanjing, China

\section{Introduction}

As an experienced scholar, Prof. Sun Wei has been engaged in the teaching and scientific research in Southeast University China, right after her graduation from Nanjing Institute of Technology in 1958. During her 50-year teaching and research, she has brought up more than 50 masters, over 40 doctors. Professor was the dean of the Department of Materials Science and Engineering, Southeast University, the deputy editor-in-chief of Journal of the Chinese Ceramic Society. She was selected as a Chinese Academy of Engineering in 2005. At this moment, she is the director of institute of fiber reinforced concrete and the director of the Jiangsu key lab for construction materials. Together with 20 of her team members, professor Sun is still very active in research and teaching on engineering cementitious materials. With her team, she has undertaken successfully for about 40 important national or international projects and published about 350 papers. With the opportunity of the International Conference on Microstructure Related Durability of Cementitious Composites held in Nanjing this October, we would like to organize a half-day workshop for celebrating her 50th year's great contribution and achievement in teaching and research. The papers presented in the workshop will be published as a special issue.

\section{Workshop venue}

International conference hotel of Nanjing, Nanjing, China (http://www.nic-hotel.com).

\section{Call for paper}

The contributions to this workshop will deal with all aspects of concrete and reinforced concrete, fiber reinforced concrete. The length of paper is limited in 15 pages (See guider for author from http://www. microdurability.com).

\section{Target audience}

The aim of this workshop is to celebrate professor Sun the 50th year's contribution and achievement in teaching and research on civil engineering materials. All of her students, colleagues and friends are welcome to join this event.

\section{Organization committee}

Professor Miao Changwen

Dr. Ye Guang

Professor Dr. Chen Huisu

Professor Dr. Zhang Yuemei

\section{Contact information}

Professor Dr. Chen Huisu (chenhs@seu.edu.cn), http://www.microdurability.com Tel:+86 25 52090645, Fax:+86 2552090667 


\section{Contents}

1 Challenges and constraints of numerical modelling of cement-based systems

Klaas van Breugel

2 Analytical modelling of hydration in traditional and innovative types of concrete

Geert De Schutter

3 Fundamentals of modeling and experimenting technology in cement based materials

Huisu Chen

4 Prediction of mechanical properties and durability of civil engineering structures

Guang Ye, Eddy Koenders and Klaas van Breugel

Part II Transport and Durability Properties

5 Transport properties of pseudo-ductile cementitious composites

Christopher K.Y. Leung and Chaoming Pang

6 Neutron radiography, a powerful method to investigate water penetration into concrete Folker H. Wittmann, Peng Zhang, Tiejun Zhao, Eberhard Lehmann and Peter Vontobel

7 The Influence of mineral admixtures on concrete anti-chloride ion permeability with stray current

Qingjun Ding, Jian Geng and Shuguang $\mathrm{Hu}$

8 Theory and application of cement-based materials remediation by Microbial Carbonate Precipitation (MCP) induced by microorganism Chunxiang Qian, Liang Cheng, Ruixing Wang and Jianyun Wang 
10 Investigation on chloride threshold level for corrosion of reinforcing steel in the saturated $\mathrm{Ca}(\mathrm{OH})_{2}$ solution simulating the electrolytic environments of concrete Jinxia $\mathrm{Xu}$ and Linhua Jiang

$11 \quad$ Katrina and climate change should we design for strength or durability? R.N. Swamy

Part III Fiber Composites and Self-Compacting Concrete

12 Engineered cementitious composite with blast furnace slag and limestone powder

Jian Zhou, Shuzhi Qian, Mercedes G. Sierra Beltran, Guang Ye and Klaas van Breugel

13 Fracture Toughness and Microstructure of Concrete at Early-Ages

Zongjin Li, Xiangyu Jin and Chen Lin

14 Simple quality control method for determining the tensile properties of strain hardening cementitious composites (SHCCs)

Shunzhi Qian and Victor C. Li

15 Development of a new self-consolidating concrete for slip form construction

Kejin Wang, Surendra P. Shah and Thomas Voigt

16 Mix proportion design of SCC based on BP network

Qingxin Zhao, Jian Wang, Jialin Ji and Huijian Li

Part IV Early Age Properties

17 Asympotic experimental study on static and dynamic moduli of ettringite crystal

Minghua Zhang, Jiankang Chen, Jue Zhu and Jiangying Chen

18 Influence of pore solution chemistry on shrinkage of cement paste 
19 Study on the shrinkage-reduction and cracking prevention of alkaliactivated phosphor slag cement

Yonghao Fang, Yiqun Chen and Lili Jia

20 Optimal determination of the cover of concrete beam under multienvironmental conditions

Chunhua Lu and Weiliang Jin

21 Application of synchrotron microtomography for microstructure investigations of cementitious materials

Michael Angelo B. Promentilla, Takafumi Sugiyama, Takashi Hitomi and

Nobufumi Takeda

Part V High Temperature and Thermal Expansion of Concrete Materials

22 Behaviour of special concretes in fire

Hans W. Reinhardt

23 Compressive strength and deformation of self-compacting concrete at

high temperature

Jin Tao, Yong Yuan and Luc Taerwe

24 Strength deterioration of high strength concrete exposed to high

temperature and its prevention and rehabilitation

Min Li, Zhishen $\mathrm{Wu}$, Chunxiang Qian and Wei Sun

25 Influence of concrete components on coefficient of thermal expansion Chunxiang Qian, Guibo Gao, Chenfeng Zhu and Shiwei Ding 